\title{
ADSORPTION AND DISSOCIATION OF H2S ON V(110), Pd(111) AND Pd OVERLAYER ON V(110) SURFACES: A DENSITY FUNCTIONAL THEORY STUDY
}

\author{
Muhammad Haris Mahyuddin \\ Department of Physics - Energy Engineering, Surya University \\ haris.mahyuddin@surya.ac.id
}

\begin{abstract}
An interesting prospective pseudomorphic overlayer on bcc surface material as implemented in $\mathrm{Pd}$ pseudomorphic overlayer on $\mathrm{V}(110)$ surface has been introduced in the frame work of first-principles calculation. Adsorption and decomposition of $\mathrm{H}_{2} \mathrm{~S}$ molecule were calculated on this overlayer structure. In comparison, we calculated them on their bare $\mathrm{V}(110)$ and $\mathrm{Pd}(111)$ surfaces. It was found that Pseudomorphic overlayer surface structure weakened the adsorption energy of $\mathrm{H}_{2} \mathrm{~S}, \mathrm{SH}, \mathrm{S}$ and $\mathrm{H}$ compared to its bare $\mathrm{Pd}(111)$ and $\mathrm{V}(110)$ surfaces. Furthermore, $\mathrm{Pd} / \mathrm{V}(110)$ surface was found to have higher activation energy barrier for $\mathrm{H}_{2} \mathrm{~S}$ and $\mathrm{SH}$ dissociation than its bare $\mathrm{Pd}(111)$ and $\mathrm{V}(110)$ do. $\mathrm{Pd} / \mathrm{V}(110)$ surface is predicted to be a promising catalyst membrane used in gas-shift reactor technology because besides its advantage to absorb hydrogen with very high permeation coefficient, sulfur atom is predicted to be adsorbed in a limited amount.
\end{abstract}

Keywords: vanadium, palladium, hydrogen sulfide, dissociative adsorption, density functional calculation

Suatu material permukaan yang dilapisi permukaan pseudomorphic seperti yang diimplementasikan dalam permukaan Pd berlapis pseudomorphic dengan permukaan V(110) telah diperkenalkan dalam kerangka kerja kalkulasi prinsip-pertama. Penyerapan dan dekomposisi molekul $\mathrm{H}_{2} \mathrm{~S}$ dihitung di atas struktur lapisan pseudomorphic ini. Sebagai perbandingan, kami juga telah menghitung itu semua di atas permukaan murni V(110) dan Pd(111). Ditemukan bahwa struktur permukaan lapis pseudomorphic memperlemah energi penyerapan $\mathrm{H}_{2} \mathrm{~S}, \mathrm{SH}, \mathrm{S}$, dan $\mathrm{H}$ jika dibandingkan ketika diserap pada permukaan murni Pd(111) dan V(110). Terlebih lagi, untuk disosiasi $\mathrm{H}_{2} \mathrm{~S}$ dan $\mathrm{SH}$ di atas permukaan $\mathrm{Pd} / \mathrm{V}(110)$ ditemukan memiliki batas energi aktifasi yang lebih tinggi daripada di atas permukaan murni Pd(111) dan V(110). Permukaan Pd/V(110) diprediksikan sebagai selaput katalis yang menjanjikan untuk digunakan pada teknologi reaktor pengubahan gas karena selain kelebihannya dalam menyerap hidrogen dalam jumlah banyak, atom sulfur pun diprediksi diserap dalam jumlah kecil.

Kata kunci: vanadium, palladium, hidrogen sulfide, penyerapan terpisah, kalkulasi fungsi kerapatan

\section{Introduction}

Hydrogen is the most promising energy carrier that can be produced from a wide variety of feedstock. Recently, the technology of hydrogen production primarily is being developed by three major methods; thermal, chemical, and biological methods. Each of them has their own advantages including high purity product, low cost production, non-reformer requirement, etc. Until today, thermal method is still the most reliable and dependable way to produce high purity hydrogen in large quantities. This advantage is required in many industrial chemical production and future energy carrier as a replacement of electricity that nowadays has been well developed and widely used. 
Thermal process which use coal gasification and is combined with the reforming process is a particular promising technology for the production of ultrahigh purity hydrogen up to $99.99 \%$ efficiency with near-zero greenhouse gas emissions (Young, 1963). This process is possible by directing streams of the mixtures gas produced from gasification against barriers membrane. The barriers are permeable to a particular selected component gas but impermeable to other gases (McKinley, 1966). Using a dense metal such as Palladium ( $\mathrm{Pd})$ as the barrier membrane, it is possible to implement such process into hydrogen production process because $\mathrm{Pd}$ is permeable enough to separate hydrogen from the contaminant gases such as $\mathrm{CO}, \mathrm{CO}_{2}$, etc. This way, one can both get the benefit of the hydrogen and discard the contaminants in a proper way.

However $\mathrm{H}_{2} \mathrm{~S}$, the most common impurities in fossil fuel based feed streams, is possible to create sulfur poisoning which greatly affects the catalytic activity of Pd membrane (Hughes, 2000). At high coverage sulfur adlayer $\left(\theta_{s}>0.5\right)$, hydrogen is unfavorable to be adsorbed on Pd surface, which will lead to reduction in hydrogen permeation through palladium membrane (Wilke et al., 1995). Furthermore, being one of the most expensive precious metals, palladium became a big challenge for commercial practicality.

It is known that body-centered cubic metals such as Vanadium (V) and Niobium (Nb) have hydrogen permeation coefficient up to 15 times higher and much more inexpensive than face-centered cubic Palladium (Uemiya, 2004 and Adhikari, 2006). However, V and Nb are easily to be oxidized, so that the dissociation of a hydrogen molecule on the metal surface is often disturbed by the formation of an oxide layer (Uemiya, 2004). Recently, this problem can be minimized by coating the surface with a palladium overlayer (Ozaki et al., 2003 and Wu et al., 1995). Ozaki et al. reported that electrolesspalladium-plated $\mathrm{V}$ and $\mathrm{V}-15 \mathrm{Ni}$ with a pretreatment of oxide removal possessed satisfactory durability and hydrogen-permeability (Ozaki et al., 2003).

Palladium overlayer is such an interesting atomic structure which its electronic properties can be dramatically changed due to the interfacial interaction. For example, Rodriguez et al. reported that admetal monolayer have electron densities that vary significantly from those of the corresponding pure metals; a pseudomorphic Pd adlayer on top of $\mathrm{Ta}(110), \mathrm{W}(110), \operatorname{Ru}(0001)$, and $\operatorname{Re}(0001)$ substrates appears to chemisorb CO in the same way as does a pure Ag surface (Rodriguez et al., 1992). In addition, Wieland et al. showed experimentally that a palladium-coated vanadium membrane (sandwich-like coating) had the highest permeation rate compared with PdAg and PdCu alloys (Wieland et al., 2002).

Studying the behavior of $\mathrm{H}_{2} \mathrm{~S}$ on $\mathrm{Pd}$ and other metal surfaces has been so much reported (Alfonso et al., 2005, Alfonso et al., 2008, Spencer et al, 2008, and Hyman et al., 2007). Such study is important in order to understand the reasons for the sulfur poisoning at many reforming process of the mixture gas. However, to the best of our knowledge, adsorption properties and dissociation mechanisms of $\mathrm{H}_{2} \mathrm{~S}$ molecule on $\mathrm{V}(110)$ and $\mathrm{Pd}$ overlayer on $\mathrm{V}(110)$ surfaces are still remain unclear.

To study the mechanism of $\mathrm{H}_{2} \mathrm{~S}$ adsorption and dissociation on $\mathrm{Pd} / \mathrm{V}(110)$ surface, we have carried out a set of calculations based on the density functional theory (DFT) on the adsorptions of $\mathrm{H}_{2} \mathrm{~S}, \mathrm{SH}$, 
and $\mathrm{S}$ on the bare $\mathrm{V}(110)$ and $\mathrm{Pd}(111)$ surfaces and on $\mathrm{Pd} / \mathrm{V}(110)$ surface. The details of the methods used and the results of these calculations are presented below.

\section{Theoretical Frameworks}

\section{FCC and BCC Bulk and Surface Structures}

Vanadium is a body centered cubic (bcc) crystal structure which consists of one atom in its primitive cell. With $\boldsymbol{a}$ is a lattice constant, bcc's primitive lattice vectors are:

$\mathrm{A}(1)=-1 / 2 a \mathrm{X}+1 / 2 a \mathrm{Y}+1 / 2 a \mathrm{Z}$

$\mathrm{A}(2)=+1 / 2 a \mathrm{X}-1 / 2 a \mathrm{Y}+1 / 2 a \mathrm{Z}$

$\mathrm{A}(3)=+1 / 2 a \mathrm{X}+1 / 2 a \mathrm{Y}-1 / 2 a \mathrm{Z}$

Palladium is a face centered cubic (fcc) crystal structure which one atom in its primitive cell. With $\boldsymbol{a}$ is a lattice constant, fcc's primitive lattice vectors are:

$\mathrm{A}(1)=1 / 2 a \mathrm{Y}+1 / 2 a \mathrm{Z}$

$\mathrm{A}(2)=1 / 2 a \mathrm{X}+1 / 2 a \mathrm{Z}$

$\mathrm{A}(3)=1 / 2 a \mathrm{X}+1 / 2 a \mathrm{Y}$

Metal surfaces were constructed from their bulk structures. Miller indices of (110) and (111) surfaces were selected for vanadium and palladium metals respectively because these respective surfaces are their most dense surfaces.

(a)

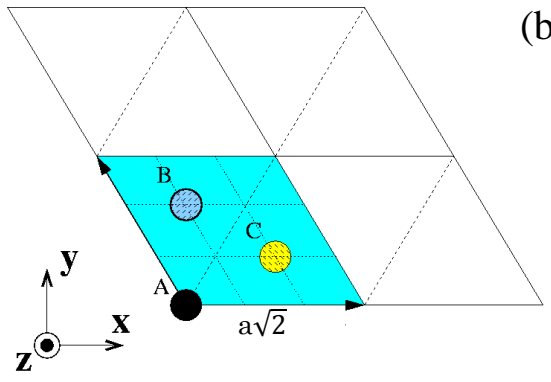

(b)

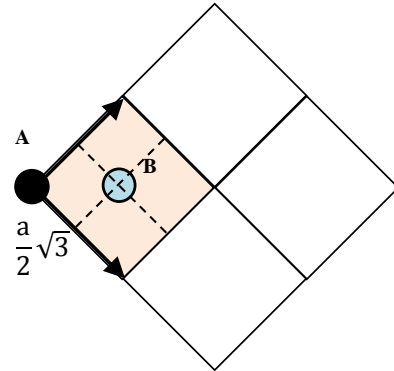

Figure 1. (a) Fcc(111) and (b) Bcc(110) Surfaces

Figure 1 shows the configuration of $\mathrm{fcc}(111)$ and $\mathrm{bcc}(110)$ surfaces. Atom A, B, and C in Figure 1 (a) is the primitive atoms which is belong to the first, second, and third layers respectively. For fcc(111) surface there are three different primitive atoms, so that there would be two different hollow sites. And for bcc(110) surface there are two different primitive atoms, so that there would be one hollow site. The arrowed lines showed in Figure 1 is the primitive lattice vectors of fcc(111) and bcc(110) surfaces. 


\section{The Slab Model}

(a)

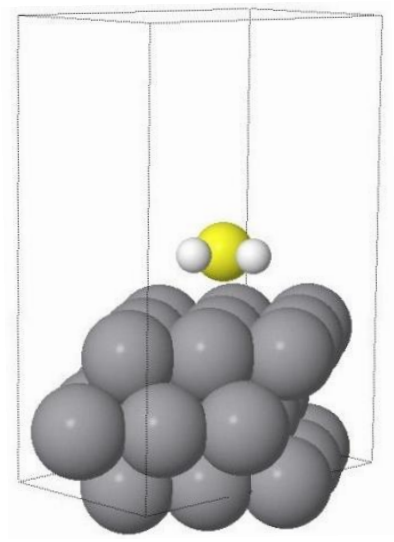

(b)

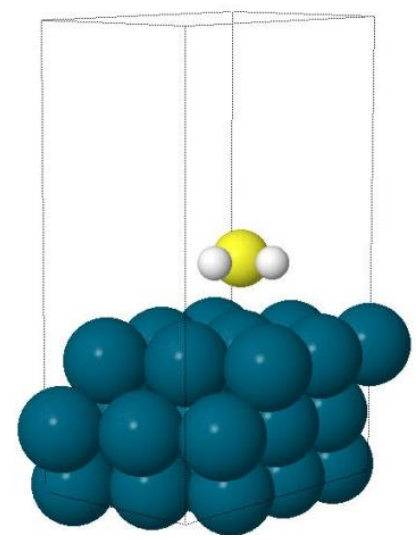

(c)

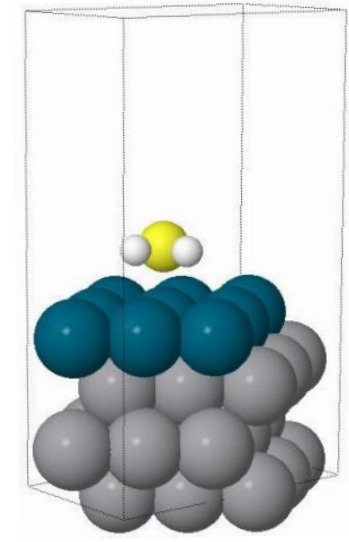

Figure 2. Slab model of (a) V(110) (b) Pd(111) (c) Pd/V(110)

The (110) and (111) structures is modeled by slab geometry. Slab model is composed of three metal layers for $\mathrm{V}(110)$ and $\mathrm{Pd}(111)$ surfaces and four metal layers for $\mathrm{Pd} / \mathrm{V}(110)$ surface and separated by $10 \AA$ of vacuum space as shown in Figure 2. A $3 \times 3$ unit cell is used to construct a metal layer, which means each layer consists of 9 metal atoms. Adsorbate species of $\mathrm{H}_{2} \mathrm{~S}, \mathrm{SH}, \mathrm{S}$, and $\mathrm{H}$ are placed on one side of the studied metal surfaces at coverage $\theta=1 / 9$ monolayer (one molecule or atom above nine metal atoms of a surface).

\section{Vienna $A b$ initio Simulation Package (VASP)}

VASP is a package for performing $a b$ initio quantum-mechanical molecular dynamics (MD) using pseudopotentials and a plane wave basis set. The approach implemented in VASP is based on a finitetemperature local-density approximation and an exact evaluation of the instantaneous electronic ground state at each MD-step using efficient matrix diagonalization schemes and an efficient Pulay mixing. These techniques avoid all problems occurring in the original Car-Parrinello method which is based on the simultaneous integration of electronic and ionic equations of motion. The interaction between ions and electrons is described using ultrasoft Vanderbilt pseudopotentials (US-PP) or the projector augmented wave (PAW) method. Both techniques allow a considerable reduction of the necessary number of plane-waves per atom for transition metals and first row elements. Forces and stress can be easily calculated and are used to relax atoms into their instantaneous ground state.

\section{Climbing Image Nudge Elastic Band (CI-NEB)}

In order to find the activation energy barrier of $\mathrm{H}_{2} \mathrm{~S}$ dissociation process, the most maximum energies along the reaction path have to be obtained. The atomic configuration with this energy is referred to as transition state, while the other maxima and minima are referred to as saddle points.

The nudged elastic band (NEB) is a method for finding saddle points and minimum energy paths (MEP) between known reactants and products (end points). The method works by optimizing a number of intermediate images along the reaction path. Each image finds the lowest energy possible while 
maintaining equal spacing to neighboring images. This constrained optimization is done by adding spring forces along the band between images and by projecting out the component of the force due to the potential perpendicular to the band. This force projection is referred to as nudging.

While the NEB method gives a discrete representation of the MEP, the energy of saddle points needs to be obtained by interpolation. However unfortunately, when the energy barrier is too narrow compared with the length of the MEP, few images land in the neighborhood of the saddle point and the interpolation can be inaccurate. The red circle in Figure 3 is the example of this phenomenon where an intermediate minimum is located along the MEP. In fact, it turns out that this minimum is deeper than the chemisorbed state at the 0.0 end points

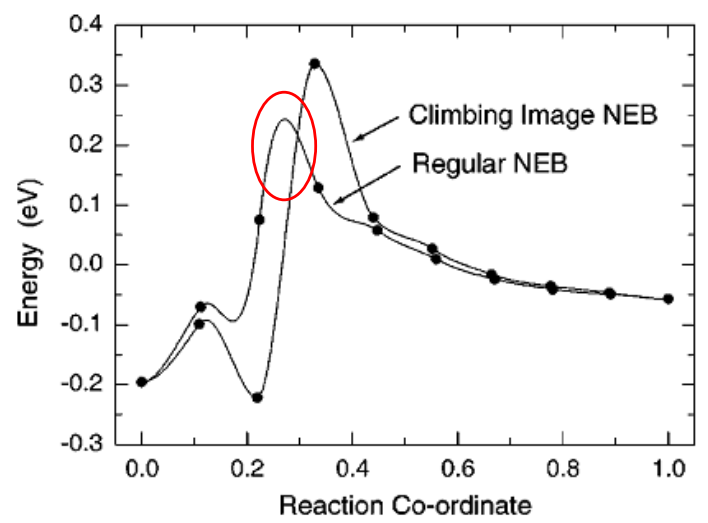

Figure 3. Comparison of NEB and CI-NEB (Henkelman et al., 2000)

The climbing image NEB (CI-NEB) is a small modification to the NEB method in which the highest energy image is driven up to the saddle point. This image does not feel the spring forces along the band. Instead, the true force at this image along the tangent is inverted. In this way, the image tries to maximize its energy along the band, and minimize in all other directions. When this image converges, it will be at the exact saddle point. This way gives not only retained information about the shape of the MEP, but also a rigorous convergence to a saddle point.

\section{Research Methodology}

All calculations were done using the Vienna Ab initio Simulation Package (VASP). Electron exchangecorrelation energy was treated by Generalized Gradient Approximation (GGA) with the implementation of Perdew and Wang (PW91). The electron-ion interaction was described by the PAW method. The plane wave energy cutoff used was $270 \mathrm{eV}$. Monkhorst-Pack $k$-point grid of size $10 \times 10 \times 10$ and $3 \times$ $3 \times 1$ were used for bulk and surface calculations respectively. Primitive lattice vector was employed in the bulk calculations. Geometry optimization were performed using quasi-Newton method and structural parameters were considered as converged when the atomic forces were less than $0.02 \mathrm{eV} / \AA$. MethfesselPaxton smearing of $\sigma=0.2 \mathrm{eV}$ was utilized to improved convergence and the corrected energy for $\sigma \rightarrow$ 0 was employed. 


\section{Calculating Adsorption Energy}

The adsorbates of $\mathrm{H}_{2} \mathrm{~S}$ and $\mathrm{SH}$ molecules were placed on one side of the studied metal surfaces with the calculated equilibrium orientation. $\mathrm{S}$ and $\mathrm{H}$ atoms were placed $2 \AA$ above one side of the metal surfaces. During calculation the molecules or atoms were fully relaxed as well as the top two (or three) layers of the studied metal surfaces.

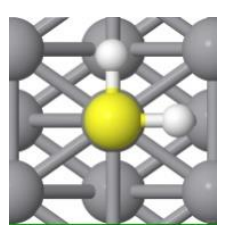

(a)

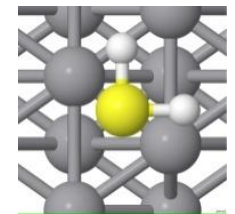

(b)

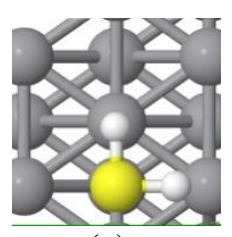

(c)

Figure 4. Adsorption Sites of Bcc Metal Surface; (a) Top, (b) Bridge, (c) Hollow sites

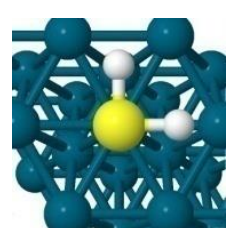

(a)

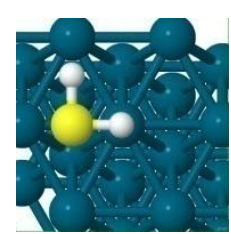

(b)

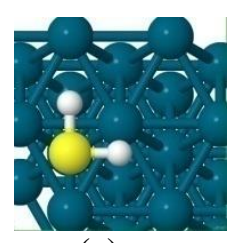

(c)

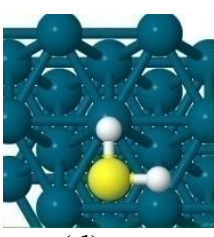

(d)

Figure 5. Adsorption Sites of Fcc Metal Surface; (a) Top, (b) Bridge, (c) Hcp, (d) Fcc sites

The calculation results were summarized to examine the adsorption site with the most minimum adsorption energy. The post-calculate geometry of the adsorbates were examined as well. The adsorption energy of the adsorbates is calculated using expression of

$E_{\text {ads }}=E_{\text {adsorbate+slab }}-\left(E_{\text {slab }}+E_{\text {adsorbate }}\right)$

where $E_{\text {adsorbate+slab }}$ is the total energy of the relaxed adsorbate-surface system, while $E_{\text {slab }}$ and $E_{\text {adsorbate }}$ are the total energy of the relaxed bare surface and gas phase adsorbate respectively. Based on this definition, a negative $E_{\text {ads }}$ indicates that the adsorption is exothermic.

The adsorption sites of bcc and fcc metal structures are respectively shown as in Figure 4 and Figure 5. Top site is defined as the site where adsorbate atom is on top of one of the atom's surface (first layer). Bridge site is defined as the site where adsorbate atom is on the between of two atom's surface. Hollow site is defined as the site where adsorbate atom is on top of one of the atom's subsurface (second layer for hcp type and third layer for fcc type). In the case of the adsorbate is a molecule, S atom would be the center of mass.

\section{Calculating Reaction Energy and Activation Energy Barrier of Dissociation Process}

$\mathrm{H}_{2} \mathrm{~S}$ dissociation process is divided by three reaction steps as follows.

$$
\begin{aligned}
& \mathrm{H}_{2} \mathrm{~S}_{(\mathrm{gas})} \rightarrow \mathrm{H}_{2} \mathrm{~S}_{(\mathrm{ad})} \\
& \mathrm{H}_{2} \mathrm{~S}_{(\mathrm{ad})} \rightarrow \mathrm{SH}_{(\mathrm{ad})}+\mathrm{H}_{(\mathrm{ad})} \\
& \mathrm{SH}_{(\mathrm{ad})} \rightarrow \mathrm{S}_{(\mathrm{ad})}+\mathrm{H}_{(\mathrm{ad})}
\end{aligned}
$$


In order to know whether each reaction is favorable, the overall reaction energy $\Delta E_{\mathrm{rxn}}$ of each reaction is calculated using the expression of

$\Delta E_{\mathrm{rxn}}=\Sigma E_{\mathrm{prod}}-\Sigma E_{\text {react }}$

Where the first and second terms represent the sum of energies of products and reactants, respectively. A negative value of $\Delta E_{\mathrm{rxn}}$ corresponds to an exothermic reaction.

In order to obtain the reaction path and transition state of $\mathrm{H}_{2} \mathrm{~S}$ dissociation, CI-NEB method is employed. The initial reactants and final reaction products of dissociation process as earlier described above are required in CI-NEB method. One image point of climbing image nudge elastic band (CI-NEB) method is employed to obtain the transition state and the activation energy barrier of $\mathrm{H}_{2} \mathrm{~S}$ dissociation. The initial reactants and final reaction products of dissociation process were assumed to proceed via the preferred binding site and the stable near-neighbor site respectively. This way, one image point would be sufficient and reasonable to obtain the transition state. The image was optimized using quasi-Newton optimization scheme until it reached the convergence in which the atomic forces on the system were less than $0.02 \mathrm{eV} / \AA$. Then, the activation energy barrier of the dissociation process can be calculated after the transition state is obtained using the expression of

$E_{a}=E_{T}-E_{I}$

Where $E_{T}$ is total energy of the transition state and $E_{I}$ is total energy of the initial state. The activation energy barrier means the energy required to dissociate the bond. The greater the activation energy barrier, the more energy is needed for dissociation to occur.

\section{Results and Discussion}

\section{Calculation of Bulk Vanadium and Palladium}

Freeze bulk calculations were done by varying lattice constant value from $2.7 \AA$ to $3.4 \AA$ for vanadium and from $3.7 \AA$ to $4.4 \AA$ for palladium. The true lattice constant is the lattice constant with the most minimum total energy. By plotting and fitting the total energy vs. lattice constant and finding the positive roots value, calculated lattice constant was obtained $2.985 \AA$ and $3.923 \AA$ for vanadium and palladium respectively. These results are in excellent agreement with experimental value of $3.03 \AA$ and $3.883 \AA$ for vanadium and palladium respectively (Kittel, 2005 and Coles, 1956).
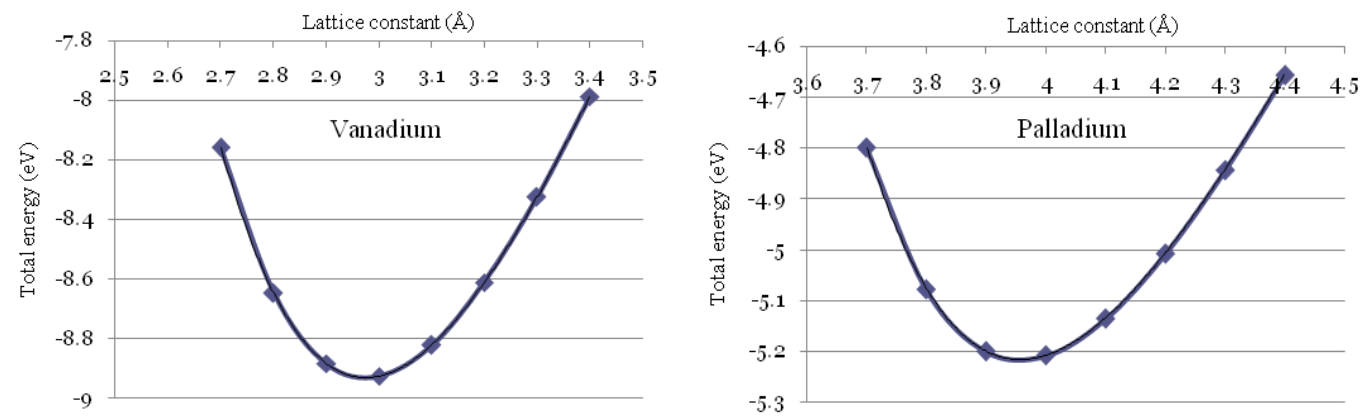

Figure 6. Calculated Lattice Constant of (a) Vanadium and (b) Palladium 


\section{Optimized Atomic Structure of The Molecules and Pseudomorphic Overlayer}

The geometry of $\mathrm{H}_{2} \mathrm{~S}$ and SH molecules were optimized in a large cell of $15 \AA \times 15 \AA \times 15 \AA$. The bond length and bond angle were found to be $1.356 \AA$ and $90.6^{\circ}$ respectively, which is in good agreement with the experiment values of $1.328 \AA$ and $92.2^{\circ}$. Similarly, the computed bond length of SH is 1.361 $\AA$, which is in good agreement with the experiment value of $1.345 \AA$ (Chase, 1989).
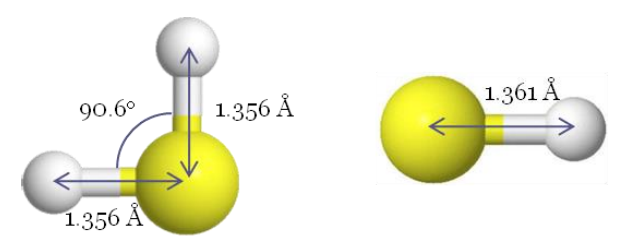

Figure 7. Optimized Atomic Structure of $\mathrm{H}_{2} \mathrm{~S}$ and SH Molecules

Overlayer structure was constructed by placing Pd adatoms at hollow sites of V(110) surface and optimized by fully relaxing the top three layers. The Pd adlayer adopted the lattice constant of vanadium rather than its own bulk lattice constant, but this was match coherently (pseudomorphic). The optimized structure of $\mathrm{Pd} / \mathrm{V}(110)$ is shown in Figure 8, where outward relaxation has been found between the first and second layers by $\Delta d_{12}=+6.2 \%$ and between the second and third layers by $\Delta d_{23}=+4 \%$. The Pd-Pd and $\mathrm{V}-\mathrm{V}$ bond length of $2.59 \AA$ did not change after optimization, and the optimized $\mathrm{Pd}-\mathrm{V}$ interatomic distance of $2.99 \AA$ amounts to a $13.3 \%$ expansion compared to $\mathrm{Pd}-\mathrm{Pd}$ or V-V bond length.

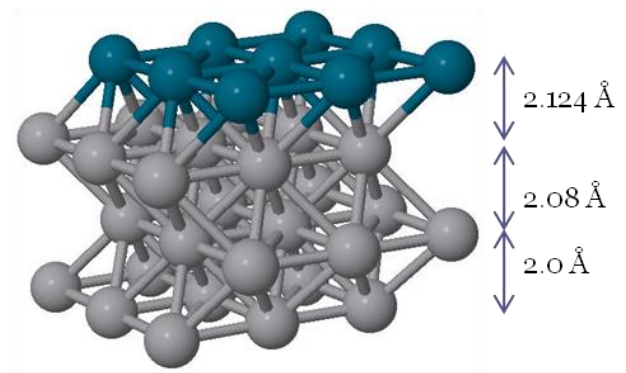

Figure 8. Optimized Atomic Structure of Pd pseudomorphic Overlayer on V(110) Surface

\section{Adsorption of $\mathrm{H}_{2} \mathrm{~S}, \mathrm{SH}, \mathrm{S}$, and $\mathrm{H}$ on the Metal Surfaces}

The computed adsorption energies and properties of $\mathrm{H}_{2} \mathrm{~S}$ are presented in Table 1. For all studied metal surfaces, the adsorption energy value is negative and S-metal distance shortened from its initial distance. This means $\mathrm{H}_{2} \mathrm{~S}$ molecule is favorable to be attracted rather than repulsed by the studied metal surfaces. The molecule was found to be adsorbed on metal surfaces via its $\mathrm{S}$ atom. The top site was found to be the most preferable site for $\mathrm{H}_{2} \mathrm{~S}$ to be adsorbed on $\mathrm{Pd}(111)$ and $\mathrm{Pd} / \mathrm{V}(110)$ surfaces. On top of $\mathrm{V}(110)$ surface, top site was also found to be stable. However, it is disfavored by $0.225 \mathrm{eV}$ relative to the hollow site. Fcc and hcp sites of Pd(111) surface were found stable by releasing energy of $0.511 \mathrm{eV}$ and 0.466 $\mathrm{eV}$ respectively. However, Alfonso reported that by using GGA-PBE method and spin-polarized calculation, $\mathrm{H}_{2} \mathrm{~S}$ was unfavorable to bind at fcc and hcp sites of $\mathrm{Pd}(111)$ surface since the molecule moved to the bridge site (Alfonso et al., 2008). In our calculation, this phenomenon occurred in the case of $\mathrm{SH}$ adsorption. 
Table 1. Adsorption Properties of $\mathrm{H}_{2} \mathrm{~S}$ on Studied Metal Surfaces

\begin{tabular}{lllcccccc}
\hline Surface & Site & $E_{\text {ads }}(\mathrm{eV})$ & $d_{\text {S-Metal }}(\AA)$ & $d_{\text {S-H1 }}(\AA)$ & $d_{\text {S-H } 2}(\AA)$ & $L_{\text {Metal-S-H1 }}\left({ }^{\circ}\right)$ & $L_{\text {Metal-S-H } 2}\left({ }^{\circ}\right)$ & $L_{\text {H-S-H }}\left({ }^{\circ}\right)$ \\
\hline $\mathrm{V}(110)$ & top & -0.530 & 2.50 & 1.37 & 1.37 & 110.2 & 110.7 & 92.2 \\
& bridge & -0.030 & 1.96 & 1.38 & 1.38 & 138.7 & 129.7 & 91.6 \\
& hollow & -0.785 & 1.95 & 1.40 & 1.40 & 114.5 & 114.7 & 92.3 \\
$\mathrm{Pd}(111)$ & top & -0.765 & 2.32 & 1.37 & 1.37 & 99.2 & 99.7 & 91.8 \\
& bridge & -0.572 & 2.04 & 1.40 & 1.38 & 99.5 & 99.2 & 91.6 \\
& Fcc & -0.511 & 1.98 & 1.39 & 1.40 & 103.9 & 103.8 & 92.0 \\
& Hcp & -0.466 & 2.11 & 1.38 & 1.38 & 98.2 & 102.1 & 90.6 \\
$\mathrm{Pd} / \mathrm{V}(110)$ & top & -0.424 & 2.50 & 1.36 & 1.36 & 102.7 & 101.7 & 91.7 \\
& bridge & -0.212 & 2.91 & 1.36 & 1.36 & 92.7 & 92.7 & 91.6 \\
& hollow & -0.197 & 2.95 & 1.36 & 1.36 & 93.5 & 92.0 & 91.9 \\
\hline
\end{tabular}

Compared to the previous first-principles study, $\mathrm{H}_{2} \mathrm{~S}$ adsorption on preferable site of $\mathrm{V}(110)$ surface releases more energy than on $\mathrm{Ag}(111), \mathrm{Au}(111)$ and $\mathrm{Cu}(111)$ as shown in Table 2, suggesting that $\mathrm{H}_{2} \mathrm{~S}$ molecule is adsorbed on $\mathrm{V}(110)$ surface stronger than on the other bare metal surfaces (Alfonso et al., 2003). However interestingly, when vanadium is covered by monolayer of palladium metals, its $\mathrm{H}_{2} \mathrm{~S}$ adsorption energy seems to be the weakest compared to its bare $\mathrm{Pd}(111)$ and $\mathrm{V}(110)$ surfaces and $\mathrm{Pd} / \mathrm{Cu}(111), \mathrm{Pd} / \mathrm{Rh}(111), \mathrm{Pd} / \mathrm{Ag}(111), \mathrm{Pd} / \mathrm{Au}(111)$ surfaces reported in the previous study (Hyman et al., 2007). It suggests that $\mathrm{H}_{2} \mathrm{~S}$ is less favorable to be adsorbed on $\mathrm{Pd} / \mathrm{V}(110)$ surface than on its bare $\mathrm{Pd}(111)$ and $\mathrm{V}(110)$ and another bimetallic surfaces. Adsorption energy of $\mathrm{H}_{2} \mathrm{~S}$ on the preferred binding site of $\mathrm{V}(110)$ differs slightly to $\mathrm{Pd}(111)$ and $\mathrm{Pt}(111)$ by $0.02 \mathrm{eV} 0.125 \mathrm{eV}$ respectively, suggesting that $\mathrm{V}(110)$ surface is in the same level as the platinum group metals in the association with $\mathrm{H}_{2} \mathrm{~S}$.

Table 2. Adsorption Energy of $\mathrm{H}_{2} \mathrm{~S}$ (in eV) on Several Bare and Alloy Metal Surfaces (Hyman et al., 2007 and Alfonso et al., 2003)

\begin{tabular}{lcccc}
\hline Metal surface & $\mathrm{H}_{2} \mathrm{~S}$ & $\mathrm{SH}$ & $\mathrm{S}$ & $\mathrm{H}$ \\
\hline $\mathrm{Ag}(111)$ & -0.17 & -2.34 & -3.94 & -2.22 \\
$\mathrm{Au}(111)$ & -0.27 & -2.23 & -3.99 & -2.29 \\
$\mathrm{Cu}(111)$ & -0.26 & -2.76 & -4.75 & -2.58 \\
$\mathrm{Pt}(111)$ & -0.91 & -3.18 & -5.38 & -2.80 \\
$\mathrm{PdAg}_{3}(111)$ & $\mathrm{N} / \mathrm{A}$ & $\mathrm{N} / \mathrm{A}$ & 3.99 & N/A \\
$\mathrm{PdCu}_{3}(111)$ & N/A & N/A & 4.47 & N/A \\
\hline
\end{tabular}

It seems in all studied metal surfaces; there are changes in $\mathrm{H}_{2} \mathrm{~S}$ geometry structure either its bond length or angle. In other word, the existence of metal surfaces below the molecule is indeed affecting the molecule's atomic structure. On the bridge and fcc sites of $\operatorname{Pd}(111)$ surface, there is slight difference $\mathrm{S}-\mathrm{H}$ bond lengths between the first and second $\mathrm{H}$ atoms, but it is negligible since they differ by less than $0.02 \AA$ A. Compared to the initial orientation of $\mathrm{H}_{2} \mathrm{~S}$ molecule, there are some changes in metal-S-H angle of all studied metals. In addition, there are also differences metal-S-H angle between the first and second $\mathrm{H}$ atoms. This means, the molecule's orientation above the studied metal surfaces changed during adsorption not only by pitch-rotating but also roll-rotating. 
Table 3. Adsorption Properties of SH on Studied Metal Surfaces

\begin{tabular}{llcccc}
\hline Metal surface & Site & $E_{\text {ads }}(\mathrm{eV})$ & $d_{\text {S-Metal }}(\AA)$ & $d_{\text {S-H }}(\AA)$ & $乙_{\text {Metal-S-H }}\left({ }^{\circ}\right)$ \\
\hline $\mathrm{V}(110)$ & top & -2.960 & 2.28 & 1.37 & 103.3 \\
& bridge & - & - & - & - \\
& hollow & -3.934 & 1.72 & 1.38 & 124.4 \\
$\operatorname{Pd}(111)$ & top & -2.387 & 2.25 & 1.37 & 98.9 \\
& bridge & -3.091 & 1.78 & 1.43 & 93.9 \\
& fcc & - & - & - & - \\
& hcp & - & - & - & - \\
$\mathrm{Pd} / \mathrm{V}(110)$ & top & -2.141 & 2.38 & 1.36 & 99.6 \\
& bridge & -2.467 & 2.09 & 1.37 & 104.2 \\
& hollow & -2.273 & 1.99 & 1.37 & 132.0 \\
\hline
\end{tabular}

The computed adsorption energies and properties of sulfuhydril are presented in Table 3. Similar to $\mathrm{H}_{2} \mathrm{~S}$, SH molecule was adsorbed to the surface via its $\mathrm{S}$ atom. $\mathrm{SH}$ molecule was found to bind preferably on hollow site of V(110) surface. Bridge site of V(110) surface seems unstable because SH molecule moved from bridge site to the hollow site during calculation. Bridge site of $\operatorname{Pd}(111)$ and $\mathrm{Pd} / \mathrm{V}(110)$ surfaces was found to be the most preferable binding site of $\mathrm{SH}$ molecule, which is in excellent agreement with Alfonso's work (Alfonso et al., 2003). Fcc and hcp sites of Pd(111) were found to be unstable since the SH molecule moved to the bridge site during calculation, which is in contrast with Alfonso's work. Furthermore, Alfonso reported that top site of $\mathrm{Pd}(111)$ was found unstable for SH molecule to bind, which is again in contrast with our result.

Again, SH molecule is adsorbed on $\mathrm{V}(110)$ surface with the highest adsorption energy compared to the noble metal surfaces ( $\mathrm{Ag}, \mathrm{Au}$ and $\mathrm{Cu}$ ) and platinum group metal surfaces (Pd and $\mathrm{Pt}$ ). $\mathrm{SH}$ molecule adsorbed on $\operatorname{Pd}(111)$ surface with energy differs by $1.9 \mathrm{eV}$ less than on $\operatorname{Pt}(111)$ surface. This places $\operatorname{Pd}(111)$ at number two in adsorption energy of SH molecule after $\mathrm{V}(110)$ surface. $\mathrm{Pd} / \mathrm{V}(110)$ surface reduces the adsorption energy up to $2.6 \mathrm{eV}$ compared to $\mathrm{V}(110)$ surface. This value is also weaker by $0.9 \mathrm{eV}$ than $\mathrm{Pd}(111)$ surface. Overlayer structure is again taking role in weakening adsorption energy.

Table 4. Adsorption Properties of S and H Atoms on Studied Metal Surfaces

\begin{tabular}{llcccc}
\hline \multirow{2}{*}{ Metal surface } & \multirow{2}{*}{ Site } & \multicolumn{2}{c}{$\mathrm{S}$ atom } & \multicolumn{2}{c}{$\mathrm{H}$ atom } \\
\cline { 3 - 6 } & & $E_{\text {ads }}(\mathrm{eV})$ & $d_{\text {S-Metal }}(\AA)$ & $E_{\text {ads }}(\mathrm{eV})$ & $d_{\text {S-Metal }}(\AA)$ \\
\hline $\mathrm{V}(110)$ & top & -5.054 & 5.08 & -2.082 & 1.74 \\
& bridge & -6.260 & 3.69 & -3.022 & 1.23 \\
$\operatorname{Pd}(111)$ & hollow & -6.681 & 1.64 & -3.173 & 1.10 \\
& top & -3.284 & 2.15 & -2.405 & 1.55 \\
& bridge & -4.701 & 1.62 & -2.758 & 0.99 \\
& fcc & -5.063 & 1.53 & -2.886 & 0.81 \\
$\operatorname{Pd} / \mathrm{V}(110)$ & hcp & -4.966 & 1.55 & -2.857 & 0.81 \\
& Top & -3.197 & 2.25 & -1.856 & 1.63 \\
& bridge & -3.770 & 1.89 & -2.137 & 1.18 \\
& hollow & -4.078 & 1.45 & -2.151 & 1.31 \\
\hline
\end{tabular}


The computed $\mathrm{S}$ and $\mathrm{H}$ adsorption energies and the distance from the adsorbate perpendicular to the metal surface are presented in Table 4. Both $\mathrm{S}$ and $\mathrm{H}$ atoms prefer the same site for each metal surface. Hollow site of $\mathrm{V}(110)$ and $\mathrm{Pd} / \mathrm{V}(110)$ were found to be the preferred binding sites, while for $\operatorname{Pd}(111)$, fcc site seems to be the preferred binding site. Both adsorption energies of $\mathrm{S}$ and $\mathrm{H}$ atoms on $\operatorname{Pd}(111)$ surface are in excellent agreement with Alfonso's work (Alfonso et al., 2003). Compared to all studied metal surfaces, $\mathrm{Pd} / \mathrm{V}(110)$ surface seems to have the weakest $\mathrm{S}$ atom adsorption energy on their preferable sites. In addition, it is also weaker than adsorption energy of $\mathrm{PdCu}_{3}$ alloy and slightly stronger than adsorption energy of $\mathrm{PdAg}_{3}$ alloy as shown in Table 2. This suggests that pseudomorphic overlayer surface is predicted to have a role to prevent sulfur adsorption as the same way as $\mathrm{PdAg}_{3}$ alloy but better than $\mathrm{PdCu}_{3}$ alloy.

Hydrogen adsorption energy was observed different between fcc and bcc metals. Adsorption energy of $\mathrm{H}$ atom on preferable site of $\mathrm{V}(110)$ surface shows $\sim 0.3 \mathrm{eV}$ stronger than on preferable site of $\operatorname{Pd}(111)$. This is as expected that vanadium adsorbs hydrogen more strongly and exothermically than palladium. Furthermore, vanadium is a hydride forming and fast hydrogen adsorbing metal which is possible to cause cracks easily (Matsui, 1984). Even though it is not as strong as palladium, $\mathrm{Pd} / \mathrm{V}(110)$ surface shows a competitive energy value of hydrogen adsorption, suggesting that such overlayer membrane would be as reliable as palladium membrane in adsorbing hydrogen. Our calculation shows that adsorption energy of $\mathrm{Pd} / \mathrm{V}(110)$ is weakened by $1.022 \mathrm{eV}$ compared to its bare $\mathrm{V}(110)$ surface. This is similar to the previous study reported by Pallassana et al., in which hydrogen is chemisorb on $\mathrm{Pd} / \operatorname{Re}(0001)$ with chemisorption energy of $-2.25 \mathrm{eV}$, which is weaker by $0.57 \mathrm{eV}$ than its bare $\operatorname{Re}(0001)$ surface (Pallassana et al., 1999).

\section{$\mathrm{H}_{2} \mathrm{~S}$ Dissociation on the Metal Surfaces}

Reaction energies of all $\mathrm{H}_{2} \mathrm{~S}$ dissociation reaction steps on studied metal surfaces are presented in Table 5. It shows that all dissociation reaction steps are energetically favorable over $\mathrm{V}(110)$ and $\mathrm{Pd}(111)$ surfaces. Compared to the noble metal surfaces shown in Table 6, our studied bare $\operatorname{Pd}(111)$ and $\mathrm{V}(110)$ surfaces have more exothermic reaction energy for each dissociation step. Reaction energies of -2.173 and $-2.005 \mathrm{eV}$ are noted as the strongest energy released by $\mathrm{V}(110)$ surface to dissociate $\mathrm{H}_{2} \mathrm{~S}$ and $\mathrm{SH}$ molecules respectively.

Table 5. Reaction Energy $\left(\Delta E_{\mathrm{rxn}}\right)$ and Activation Energy Barrier $\left(E_{\mathrm{a}}\right)$ of $\mathrm{H}_{2} \mathrm{~S}$ Dissociation on Studied Metal Surfaces

\begin{tabular}{lccccc}
\hline \multirow{2}{*}{ Metal surface } & $\mathrm{I}_{2} \mathrm{H}_{2} \mathrm{~S}_{(\mathrm{gas})} \rightarrow \mathrm{H}_{2} \mathrm{~S}_{(\mathrm{ad})}$ & \multicolumn{2}{c}{$\mathrm{II} . \mathrm{H}_{2} \mathrm{~S}_{(\mathrm{ad})} \rightarrow \mathrm{SH}_{(\mathrm{ad})}+\mathrm{H}_{(\mathrm{ad})}$} & \multicolumn{2}{c}{$\mathrm{III} . \mathrm{SH}_{(\mathrm{ad})} \rightarrow \mathrm{S}_{(\mathrm{ad})}+\mathrm{H}_{(\mathrm{ad})}$} \\
\cline { 2 - 6 } & $\Delta E_{\mathrm{rxn}}(\mathrm{eV})$ & $\Delta E_{\mathrm{rxn}}(\mathrm{eV})$ & $E_{\mathrm{a}}(\mathrm{eV})$ & $\Delta E_{\mathrm{rxn}}(\mathrm{eV})$ & $E_{\mathrm{a}}(\mathrm{eV})$ \\
\hline $\mathrm{V}(110)$ & -0.785 & -2.173 & 0.698 & -2.005 & 0.057 \\
$\mathrm{Pd}(111)$ & -0.765 & -1.065 & 0.056 & -0.942 & 0.184 \\
$\mathrm{Pd} / \mathrm{V}(110)$ & -0.424 & -0.045 & 2.858 & 0.151 & 1.055 \\
\hline
\end{tabular}


$\mathrm{H}_{2} \mathrm{~S}$ dissociation on $\mathrm{Pd} / \mathrm{V}(110)$ was found favorable as well as SH dissociation with a very slight energy released. The third dissociation step on $\mathrm{Pd} / \mathrm{V}(110)$, which is $\mathrm{SH}$ dissociate to $\mathrm{S}$ and $\mathrm{H}$ atoms, was found unfavorable since its reaction energy was slightly endothermic. In the view point of sulfur poisoning, this is a good indication since the abstraction of $\mathrm{S}$ atom from $\mathrm{SH}$ molecule on $\mathrm{Pd} / \mathrm{V}(110)$ surface will face barrier to couple with. The same behavior was also occurred to $\mathrm{Pd} / \mathrm{Cu}(111)$ surface reported by Hyman et al. as shown in Table 6 (Hyman et al., 2007).

Table 6. Reaction Energy $\left(\Delta E_{\mathrm{rxn}}\right)$ and Activation Energy Barrier $\left(E_{\mathrm{a}}\right)$ of $\mathrm{H}_{2} \mathrm{~S}$ Dissociation on Several Overlayer Bimetallic Systems and Bare Metal Surfaces

\begin{tabular}{lcccc}
\hline \multirow{2}{*}{ Metal surface } & \multicolumn{2}{c}{$\mathrm{H}_{2} \mathrm{~S}_{(\mathrm{ad})} \rightarrow \mathrm{SH}_{(\mathrm{ad})}+\mathrm{H}_{(\mathrm{ad})}$} & \multicolumn{2}{c}{$\mathrm{SH}_{(\mathrm{ad})} \rightarrow \mathrm{S}_{(\mathrm{ad})}+\mathrm{H}_{(\mathrm{ad})}$} \\
\cline { 2 - 5 } & $\Delta E_{\mathrm{rxn}}(\mathrm{eV})$ & $E_{\mathrm{a}}(\mathrm{eV})$ & $\Delta E_{\mathrm{rxn}}(\mathrm{eV})$ & $E_{\mathrm{a}}(\mathrm{eV})$ \\
\hline $\mathrm{Pd} / \mathrm{Cu}(111)$ & -0.28 & $\mathrm{~N} / \mathrm{A}$ & 0.25 & N/A \\
$\mathrm{Pd} / \mathrm{Rh}(111)$ & -0.49 & $\mathrm{~N} / \mathrm{A}$ & -0.3 & N/A \\
$\mathrm{Pd} / \mathrm{Ag}(111)$ & -1.1 & $\mathrm{~N} / \mathrm{A}$ & -0.72 & N/A \\
$\mathrm{Pd} / \mathrm{Au}(111)$ & -1.15 & $\mathrm{~N} / \mathrm{A}$ & -0.69 & N/A \\
$\mathrm{Ag}(111)$ & -0.15 & 0.86 & 0.12 & 1.06 \\
$\mathrm{Au}(111)$ & 0.02 & 0.72 & 0.02 & 0.68 \\
$\mathrm{Cu}(111)$ & -0.80 & 0.43 & -0.60 & 0.40 \\
$\mathrm{Pt}(111)$ & -0.85 & 0.07 & -0.79 & 0.03 \\
\hline
\end{tabular}

As shown in Table 5, the abstraction of $\mathrm{SH}$ and $\mathrm{H}$ from $\mathrm{H}_{2} \mathrm{~S}$ on each studied metal surfaces needs an amount of energy to overcome the activation barrier. This explains that between adsorption and dissociation process there is an energy condition has to be fulfilled. The platinum group metals ( $\mathrm{Pd}$ and $\mathrm{Pt}$ ) have similar activation energy barrier that is very slight barrier. Compared to the noble metals shown in Table 6, the activation energy barrier of $\mathrm{V}(110)$ surface is larger than $\mathrm{Cu}(111)$ but slightly smaller than $\mathrm{Ag}(111)$ and $\mathrm{Au}(111)$ surfaces. This suggest that the catalytic activity of $\mathrm{V}(111)$ in the presence of hydrogen sulfide molecule is as good as $\mathrm{Ag}$ and $\mathrm{Cu}$ surfaces. As hoped that $\mathrm{Pd} / \mathrm{V}(110)$ surface has bigger activation energy barrier than its bare $\operatorname{Pd}(111)$ and $\mathrm{V}(110)$ surfaces do. It is noted that about $3 \mathrm{eV}$ of energy is required in order for reaction of $\mathrm{H}_{2} \mathrm{~S}$ dissociation to proceed.

The abstraction of $\mathrm{S}$ and $\mathrm{H}$ atoms from $\mathrm{SH}$ molecule on $\mathrm{V}(110)$ has a very small activation energy barrier to be achieved before releasing so much energy. This means SH dissociation on V(110) surface is a facile and exothermic process. This phenomenon is similar to $\mathrm{SH}$ dissociation on $\mathrm{Pt}(111)$ shown in Table 6 which has the same low activation barrier but slight exothermic process. On $\operatorname{Pd}(111)$ surface, dissociation of SH molecule also has small activation energy barrier even though it is bigger by 0.127 $\mathrm{eV}$ than on $\mathrm{V}(110)$ surface. This suggests that $\mathrm{SH}$ dissociation on $\mathrm{Pd}(111)$ surface is also a facile and slight exothermic process. $\mathrm{Pd} / \mathrm{V}(110)$ surface interestingly, the slight endothermic reaction energy of SH dissociation is followed by its quite big activation energy barrier. As shown in Table 5. $\mathrm{Pd} / \mathrm{V}(110)$ surface needs $1.055 \mathrm{eV}$ of energy to overcome the activation barrier and extra energy of $0.151 \mathrm{eV}$ to proceed the reaction. 


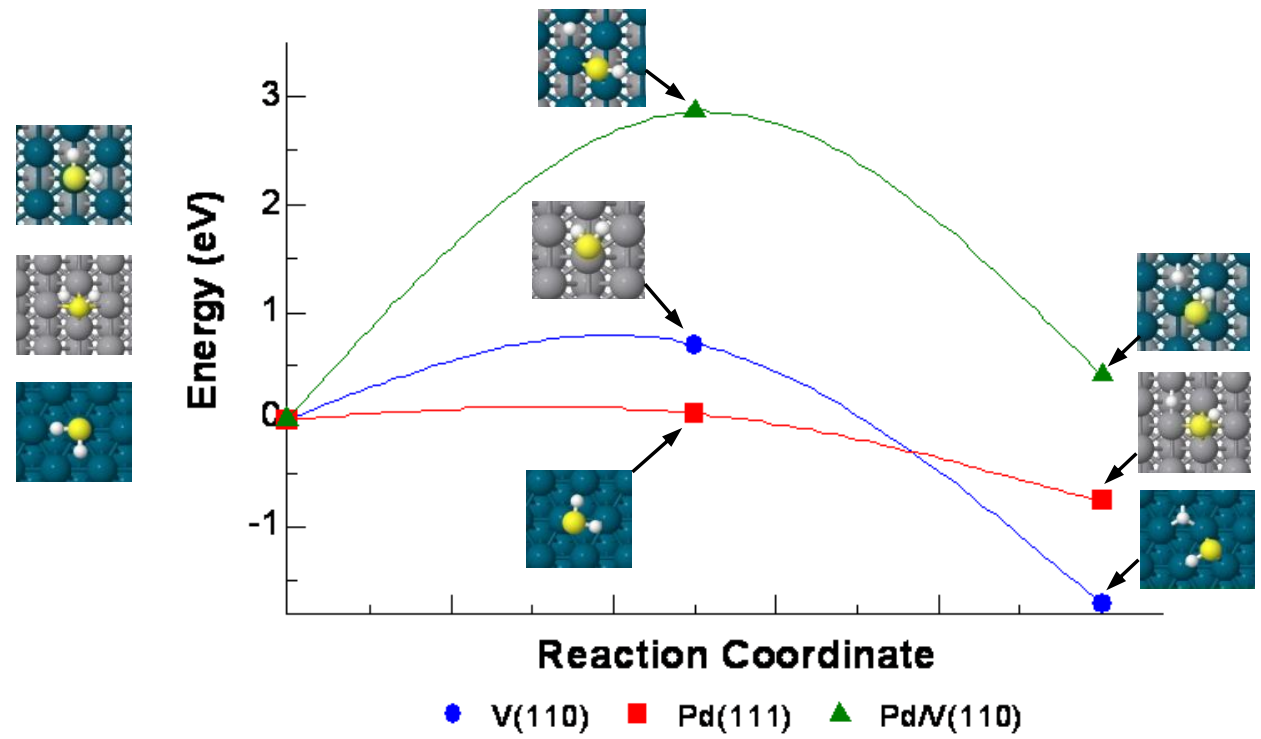

Figure 9. Minimum Energy Path for the Abstraction of $\mathrm{SH}$ and $\mathrm{H}$ from $\mathrm{H}_{2} \mathrm{~S}$ on Metal Surfaces

As shown in Figure 10, The more positive energy value at the end point than at the transition state of $\mathrm{Pd} / \mathrm{V}(110)$ surface indicates that such configuration, where $\mathrm{S}$ and $\mathrm{H}$ atoms are still bonded at the end point, did not wor $\mathrm{k}$ in determining a good transition state by CI-NEB method. It will be our concern to evaluate the mistake and recalculate a better configuration.

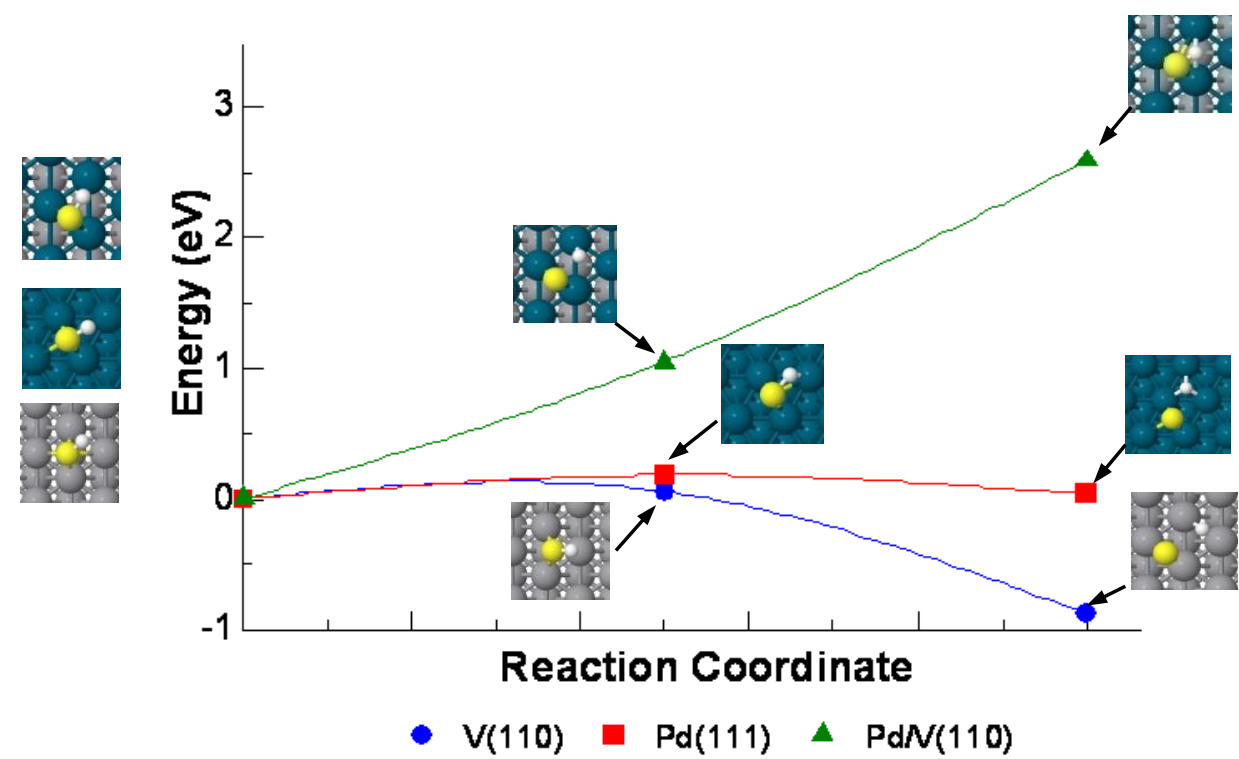

Figure 10. Minimum Energy Path for The Abstraction of S and H from SH on Metal Surfaces

The geometry properties of $\mathrm{H}_{2} \mathrm{~S}$ dissociation at the transition state is presented in Table 7. One that can be learned from this geometry is that repulsion between molecules/atoms. From the table we infer that $\mathrm{Pd} / \mathrm{V}(110)$ surface gives the highest repulsion to $\mathrm{SH}$ molecule and $\mathrm{S}$ and $\mathrm{H}$ atoms, while $\mathrm{Pd}(111)$ surface placed in the lowest repulsion after V(110) surface. Elongation of S-H bond at transition state was noted with range of 0.03 to $1.67 \AA$. The highest elongation is belong to $\mathrm{Pd} / \mathrm{V}(110)$ surface. 
Table 7. Geometry Properties of The Transition State of $\mathrm{H}_{2} \mathrm{~S}$ Dissociation on Metal Surfaces

\begin{tabular}{cccc}
\hline & $d_{\text {S-Metal }}(\AA)$ & $d_{\text {s-H1 }}(\AA)$ & $d_{\text {s-H2 }}(\AA)$ \\
\hline $\mathrm{V}(110)$ & & & \\
$\mathrm{H}_{2} \mathrm{~S}_{(\mathrm{ad})} \rightarrow \mathrm{SH}_{(\mathrm{ad})}+\mathrm{H}_{(\mathrm{ad})}$ & 2.85 & 1.39 & 1.36 \\
$\mathrm{SH}_{(\mathrm{ad})} \rightarrow \mathrm{S}_{(\mathrm{ad})}+\mathrm{H}_{(\mathrm{ad})}$ & 1.81 & 1.39 & - \\
$\mathrm{Pd}(111)$ & & & \\
$\mathrm{H}_{2} \mathrm{~S}_{(\mathrm{ad})} \rightarrow \mathrm{SH}_{(\mathrm{ad})}+\mathrm{H}_{(\mathrm{ad})}$ & 2.29 & 1.47 & 1.38 \\
$\mathrm{SH}(\mathrm{ad}) \rightarrow \mathrm{S}_{(\mathrm{ad})}+\mathrm{H}_{(\mathrm{ad})}$ & 1.74 & 1.53 & - \\
$\mathrm{Pd} / \mathrm{V}_{(110)}$ & & & \\
$\mathrm{H}_{2} \mathrm{~S}_{(\mathrm{ad})} \rightarrow \mathrm{SH}_{(\mathrm{ad})}+\mathrm{H}_{(\mathrm{ad})}$ & 2.22 & 3.03 & 1.38 \\
$\mathrm{SH}_{(\mathrm{ad})} \rightarrow \mathrm{S}_{(\mathrm{ad})}+\mathrm{H}_{(\mathrm{ad})}$ & 2.05 & 2.08 & - \\
\hline
\end{tabular}

\section{Conclusions}

We have studied $\mathrm{H}_{2} \mathrm{~S}$ adsorption and dissociation on $\mathrm{V}(110), \mathrm{Pd}(111)$, and $\mathrm{Pd} / \mathrm{V}(110)$ surfaces using a DFT approach to understand the effects of Pd overlayer on $\mathrm{V}(110)$ surface. For $\mathrm{H}_{2} \mathrm{~S}$ adsorption on $\mathrm{V}(110), \operatorname{Pd}(111)$, and $\mathrm{Pd} / \mathrm{V}(110)$ surfaces, the molecule is preferably adsorbed on the hollow, top, and top sites respectively with the $\mathrm{H}$ atoms up and the $\mathrm{S}$ atom lies closest to the metal surfaces. It has been found that addition of Pd layer on $\mathrm{V}(110)$ surface lowers the adsorption energy of $\mathrm{H}_{2} \mathrm{~S}$ molecule by 0.361 and $-0.341 \mathrm{eV}$ as compared with that on bare $\mathrm{V}(110)$ and $\mathrm{Pd}(111)$ surfaces respectively. When the $\mathrm{H}_{2} \mathrm{~S}$ molecule dissociates into $\mathrm{H}$ and $\mathrm{S}$ atoms, the $\mathrm{S}$ atom is preferably adsorbed on the respective hollow, hollow-fcc, and hollow sites of $\mathrm{V}(110), \mathrm{Pd}(111)$, and $\mathrm{Pd} / \mathrm{V}(110)$ surfaces. The adsorption energy of $\mathrm{S}$ atom on $\mathrm{Pd} / \mathrm{V}(110)$ surface is found to be $-4.078 \mathrm{eV}$, which is lowered by -2.603 and $-0.985 \mathrm{eV}$ as compared with that on bare $\mathrm{V}(110)$ and $\mathrm{Pd}(111)$ surfaces respectively.

Through the analysis of minimum energy path by using CI-NEB method, it is found that of $\mathrm{H}_{2} \mathrm{~S}$ and SH dissociation reactions on $\mathrm{V}(110)$ and $\mathrm{Pd}(111)$ surfaces are both energetically favorable. Whereas for $\mathrm{Pd} / \mathrm{V}(110)$ surface, only the $\mathrm{H}_{2} \mathrm{~S}$ dissociation reaction is favorable. The activation energy barrier for $\mathrm{H}_{2} \mathrm{~S}$ and $\mathrm{SH}$ dissociations on $\mathrm{Pd} / \mathrm{V}(110)$ surface are 2.858 and $1.055 \mathrm{eV}$ respectively. The former is higher by 2.16 and $2.802 \mathrm{eV}$ and the latter is higher by 0.998 and $0.871 \mathrm{eV}$ than those on bare $\mathrm{V}(110)$ and $\operatorname{Pd}(111)$ surfaces respectively.

The above results indicate that $\mathrm{Pd} / \mathrm{V}(110)$ surface is very effective to hinder adsorption and dissociation of $\mathrm{H}_{2} \mathrm{~S}$ molecule and $\mathrm{S}$ atom and hence sulfur poisoning can be prevented. In addition, it has advantage in absorbing hydrogen molecule with very high permeation coefficient (Wieland et al., 2002). Therefore, Pd overlayer on $\mathrm{V}(110)$ is predicted to be a promising catalyst membrane used in water-gas shift reaction technology for hydrogen production. 


\section{References}

Adhikari, S., Fernando, S. 2006. Hydrogen membrane separation techniques. Industrial \& Engineering Chemistry Research 45, 875.

Alfonso, D.R., Cugini, A.V. and Sholl, D. S. 2003. Density functional theory of sulfur binding on Pd, $\mathrm{Cu}$, and $\mathrm{Ag}$ and their alloys. Surface Science 546, 12.

Alfonso, D.R., Cugini, A.V. and Sorescu, D.C. 2005. Adsorption and decomposition of $\mathrm{H}_{2 \mathrm{~S}}$ on $\mathrm{Pd}(111)$ surface: A first-principle study. Catalysis 99, 315.

Alfonso, D.R. 2008. First-principles studies of $\mathrm{H}_{2} \mathrm{~S}$ adsorption and dissociation on metal surfaces. Surface Science 602, 2758.

Chase, J.M.W. 1989. NIST-JANAF Thermochemical Tables. Hemisphere: New York.

Coles, B. R. 1956. Journal of the Institute of Metal 84, 346.

Henkelman, G., Jonsson, H. 2000. A climbing image nudged elastic band method for finding saddle points and minimum energy paths. Chemical Physics 113, 9901.

McKinley, D.L., Nitro, W. V. Method for hydrogen separation and purification. United States Patent Office 3 (247), 648.

Hughes, R. 2000. Composite of palladium membranes for catalytic membrane reactor. Membrane Technology 131, 9.

Hyman, M.P., Loveless, B.T., Medlin, J.W. 2007. A density functional theory study of $\mathrm{H}_{2} \mathrm{~S}$ decomposition on the Pd(111) surfaces of model Pd-alloys. Surface Science 601, 5382.

Kittel, C. 2005. Introduction to Solid State Physics ( $8^{\text {th }}$ Ed). New York: John Willey \& Sons.

Matsui, H. 1984. Hydrogen embrittlement in vanadium and niobium. Science reports of the Research Institutes, Tohoku University. Ser. A 32, 78.

Ozaki, T., Zhang, Y., Komaki M., and Nishimura, C. 2003. Preparation of palladium-coated V and V-15 $\mathrm{Ni}$ membranes for hydrogen purification by electroless plating technique. International Journal of Hydrogen Energy 28, 297.

Pallassana, V., and Neurock, M. 1999. Theoretical analysis of hydrogen chemisorption on Pd(111), $\operatorname{Re}(0001), \mathrm{Pd}_{\mathrm{m} /} / \mathrm{re}(0001)$ and $\mathrm{Re}_{\mathrm{m} /} / \mathrm{Pd}(111)$ pseudomorphic overlayers. Physical Review B 60, 6146.

Rodriguez, J.A., Goodman, D. 1992. The nature of the metal-metal bond in bimetallic surfaces. Science 257 (5072), 897.

Spencer, M.J.S., Todorova, N., Yarovsky, I. 2008. $\mathrm{H}_{2} \mathrm{~S}$ dissociation on the $\mathrm{Fe}(100)$ surface: an ab-initio molecular dynamics study. Surface Science 602, 1547.

Uemiya, S. 2004. Brief review of steam reforming using a metal membrane reactor. Top Catalysis 29, 79.

Wieland, S., Melin, T., Lamm, A. 2002. Membrane reactors for hydrogen production. Chemical Engineering Science 57, 1571. 
Wilke, S., Scheffler, M. 1995. Poisoning of $\mathrm{Pd}(100)$ for the dissociation of $\mathrm{H}_{2}$ : a theoretical study of coadsorption of hydrogen and sulfur. Surface Science 329, L605.

Wu, R., Freeman, A.J. 1995. Bonding mechanism at bimetallic interfaces: Pd overlayer on various substrates. Physical Review B 52, 12419.

Young, J.R. 1963. Palladium-diaphragm hydrogen pump. Review of Scientific Instruments 34, 894. 